\title{
Impact of Destination Image and Satisfaction on Tourist Loyalty: Mountain Destinations in Thanh Hoa Province, Vietnam
}

\author{
Hoang Ba Huyen LE*, Thi Binh LE**
}

Received: January 21, 2020 Revised: February 24, 2020 Accepted: March 1, 2020.

\begin{abstract}
The study aims to assess the impact of destination image, satisfaction and loyalty of tourists at mountain destinations in Thanh Hoa province, Vietnam. The study involves questionnaire surveys and multivariate data analysis methods (Cronbach Alpha test, EFA, CFA, SEM). Research results from 500 tourists in the mountain destinations of Thanh Hoa province demonstrate that all factors have imposed a positive impact on tourist satisfaction, specifically: The most influential factor is Natural features, followed by Human factors while the least influential factor is Infrastructure; On the other hand, research results also demonstrate that satisfaction has a substantial impact on tourist loyalty. Based on the research results, we also proposed some key solutions to enhance the destination image, thereby contributing to increased satisfaction and loyalty of tourists, including: (i) Promoting Natural Tourism Resources. (ii) Raising Awareness of Environmental Protection. (iii) Building Local Cultural Identity. (iv) Building Exclusive Tourist Products. (5) Strengthening the Support of Local Authorities for Tourism Activities. (vi) Developing a Price Policy.
\end{abstract}

Keywords: Loyalty, Satisfaction, Destination Image, Mountain Region, Thanh Hoa Province.

JEL Classification Code: M31, M38, C50, D71

\section{Introduction}

Developing sustainable tourism activities tends to depend heavily on the return of tourists. The revisit intention reflects the wishes and pledges of their loyalty to a destination. Retaining costs for loyal and familiar tourist groups tend to be lower than activities that attract new tourists. Therefore, in order to retain tourists to mountain destinations, it is imperative to develop appealing tourist attractions at the destinations. In addition to relying on the natural and humanistic tourism resources, tourism

*First Author and Corresponding Author. Dean, Faculty of Economics and Business Administration, Hong Duc University, Vietnam [Postal Address: No 565, QuangTrung, Dong Ve Ward, Thanh Hoa City, Thanh Hoa Province, 40000, Vietnam] Tel: (+84) 912.222.345, Email: lehoangbahuyen@hdu.edu.vn ${ }^{* *}$ Lecturer, Faculty of Economics and Business Administration, Hong Duc University, Vietnam. Email: lethibinhkt@hdu.edu.vn

(c) Copyright: The Author(s)

This is an Open Access article distributed under the terms of the Creative Commons Attribution Non-Commercial License (http://Creativecommons.org/licenses/by-nc/4.0/) which permits unrestricted noncommercial use, distribution, and reproduction in any medium, provided the original work is properly cited. destinations in mountain areas should make every effort to provide absolute satisfaction for tourists to induce their loyalty. This can be made through the development of enticing destination attributes or tourist brands that are appealing to tourists (Zhang, Fu, Cai, \& Lu, 2014; Ba, Thu, Chi, Thanh, \& Huy, 2020).

Chon and Olsen (1991) found that there have been many different studies evaluating the correlation between destination image and tourist satisfaction and Factors affecting the satisfaction and loyalty of tourists all over the world (Chi \& Qu, 2008; Um, Chon, \& Ro, 2006; Sun, Chi, $\& \mathrm{Xu}, 2013$; Wu, 2016) and Vietnam (Pham \& Dao, 2017). However, most of these studies were conducted for general tourism destinations such as marine tourism (Sun, Chi, \& $\mathrm{Xu}, 2013$ ), resort tourism (Pham \& Dao, 2017) or religion tourism (Piewdang, Mekkamol, \& Untachai, 2013; Nyaupane, Timothy, \& Poudel, 2015).

Mountain tourism is different from other forms of tourism due to its natural resources and regional cultural characteristics. Development of tourism in mountain areas does not merely depend on available natural resources but 
also involves the contribution of local authorities, businesses and communities to develop unique attractions and brands for tourism destinations to allure potential tourists.

In this background, the study "The impact of destination image, satisfaction on the tourist's loyalty at mountain destinations in Thanh Hoa province, Vietnam" is of utmost importance.

\section{Literature Review}

\subsection{Destination Image and Constituent Factors}

Destination image study teams usually consider destination images to be one of the most crucial factors to attract and retain tourists. An enticing destination image promotes the tourist's experience and creates satisfaction that encourages tourists to return (Sun, Chi, \& Xu, 2013; Lee, 2009; Phan, 2016; Lee, \& Syah, 2018).

According to Vengesayi (2003), the factors categorized as a destination's resources (tourism resources) and the combination of tourist activities are the basic factors that make up the attractions of a tourism destinations and instill a destination image in the minds of tourists. Specifically, these are natural factors, history, culture, events and tourism and entertainment activities at a destination.

San Martín and Rodríguez Del Bosque (2008) suggested that there were five different factors that make up a destination image: Infrastructure system, climatic conditions, natural conditions, destination impression and cultural environment.

As such, it can be seen that the tourist attractiveness delivered by local attributes or destination image was measured by relatively different methods between these studies. San Martín and Rodríguez Del Bosque (2008) shown that Attractiveness can be assessed through infrastructure utilities, services, and culture or local government support and many other attributes.

\subsection{Tourist Satisfaction}

Despite being a popular research concept in marketing, satisfaction does not convey the same meaning among researchers. In fact, it is a multi-dimensional concept that includes customer product reviews and satisfaction with sale procedures and after-sale services; satisfaction with service quality and overall experience with service providers (Homburg \&Gierin, 2001).

In tourism, tourist satisfaction is always the first and foremost factor for the successful promotion of a tourism destination. Kozak and Rimmington (2000) found that tourist satisfaction affects the choice of destination, the consumption of products, services and revisit decisions. Chon (1989) states that: Tourist satisfaction depends on tourist expectations: whether pre-visit expectations match with ongoing experiences during a visit at a tourism destination (what tourists see, feel and perceive).

According to Tribe and Snaith (1998), tourist satisfaction assessment is based on a correlation directly proportional with the quality of the services provided at a destination throughout the course of the tourist perception, whereas the tourist satisfaction is assessed as a crucial factor in the development of leisure activities and tourism activities (Lee, 2009; Mannell \& Iso-Ahola, 1987).

Creating tourist satisfaction is the key to the success of tourism businesses. In addition, tourist satisfaction with mountain destinations also reflects the actual performance of tourism services offered by tourism businesses and local community. Satisfaction reflects the ability of businesses to survive and upscale their business activities (Sun, Chi, \& $\mathrm{Xu}, 2013)$. Forging tourist satisfaction can help a tourism destination reduce complaints, increase usage of services and inspire a tourist's revisit intention or drive more positive attitudes towards the destination.

\subsection{Tourist Loyalty}

The study of tourist loyalty to tourism destinations is an interesting topic for many researchers in Vietnam and all over the world. Most studies of tourist loyalty are associated with either destination image, satisfaction or service quality.

Loyalty is deemed as the tourist's intention to revisit the destination, or to encourage and recommend others to visit the destination. For tourism destinations, tourists who are satisfied with a destination tend to be more loyal to that destination (Yoon \& Uysal, 2005; Lee, 2009).

A study by Bigne, Sanchez and Sanchez (2001) developed a model to evaluate tourist's revisit intention based on the indirect impact of destination image. This study cited evidence of the apparent impact of destination image on perception of service quality, and tourist satisfaction on revisit intention and travel readiness.

Pham (2002) study on sustainable tourism development in Vietnam, this is a conventional study that analyzes fundamental principles for sustainable development, and indicators of sustainable economic, social and environmental development. The study focused on assessing the current exploitation of tourism resources in Vietnam. The experience of international tourism development was also analyzed by the study team to propose feasible solutions to manage tourism resources, market research, research and development of tourism products, training, promotion, application of scientific and technological research, and development of community- 
based tourism.

A study by Nguyen, Nguyen, and Tran (2012) on community tourism was also conducted in An Giang. The authors analyzed the factors affecting local people's decision on participation in community tourism in An Giang province, where garden tourism has witnessed a robust growth along with typical river tours. Using binary logistic regression model, the study found out five factors influencing local people's decision to participate in community tourism: Educational attainment of the household head, family size, family income, social capital and traditional occupations. Among these factors, family size has the strongest impact on local people's decisions to participate in community tourism.

Um, Chon, and Ro (2006) developed a study based on the Bigne, Sanchez and Sanchez (2001) study with the addition of money value factor. This study also focuse on explaining what factors affect the tourist's revisit intention. The study pointed out that first-time tourists decide to visit a destination as a result of the diffusion process in the society, where opinions related to tourism destinations are communicated. First-time tourists are viewed as people who have an open minded attitude that is likely to accept innovations. This study suggested to consider the revisit intention as an extension of tourist satisfaction as well as an premise of the decision-making process to revisit the destination.

In a recent study by Sun, Chi, and $\mathrm{Xu}$ (2013) on the intention to revisit a marine tourism destination (Hainan Island - China). The authors also conducted the study based on the theory of destination image combined with the sense of familiarity, in which the degree of familiarity of the destination showed an impact on the formation of destination image in the minds of tourists, thereby maintaining such an impact on tourists' perceived values and satisfaction. Moreover, tourists' perceived values and satisfaction were also assumed to play a leading role in tourist loyalty to the destination. The model also proposed a correlation between tourists' perceived values and satisfaction.

$\mathrm{Wu}$ (2016) explored international tourist loyalty to tourism destinations through the development of a model based on theory's planned behavior. Specifically, this study developed and validated a model that links destination personality and tourism destination identity with tourist loyalty, positive word of mouth information and revisit intention. Proposed factors include (1) loyalty, (2) satisfaction, (3) destination image, (4) tourist experience.

A study by Phan and Dao (2017) on the impact of destination image and emotional value on the level of satisfaction and loyalty of tourists to Dalat City. The authors have built an analytical framework focusing on aspects of generating destination image or destination enticement including: (1) Natural features; (2) Travel resources; (3) Infrastructure and (4) Government support in relation to tourist satisfaction, emotion value and loyalty to the tourism destination.

\subsection{Correlation between Destination Image and Tourist Satisfaction}

Destination image is an attribute of an enchanting tourism destination. Therefore, a good destination image will be a factor that impacts the perception of tourists to the tourism destination. Ibrahim and Gill (2005) showed a correlation between destination image and tourist satisfaction after experiencing travel products and services. In general, it can be observed that if a destination image can prove its enticement and meets the tourists' expectations, they will be likely to achieve even more satisfaction. Crosby, Evans, and Cowles (1990) found that it comes as no surprise that satisfaction stems from comparing expectations with actual experience of products and services in reality.

\subsection{Correlation between Tourist Satisfaction and Destination Loyalty}

Many available studies confirmed a significant correlation between tourist satisfaction and loyalty. Kim and Park (2019) show that customer satisfaction contributes positively to customer delight, and that customer delight plays a significant role in the relationship between customer satisfaction and loyalty. Satisfaction directly and positively impacts tourist loyalty (Zeithaml, Berry, \& Parasuraman, 1996; Cronin \& Taylor, 1992; Kotler, Ang, Leong, \&Tan, 1996)

In the tourism industry, convincing evidences are available to prove that: a positive correlation exists between tourist satisfaction and future plans to revisit and recommend destinations to others (Kozak \& Rimmington, 2000; Yoon \& Uysal, 2005). This conclusion was convincingly affirmed by Lee (2009).

For a tourism destination, tourist satisfaction is likely to stimulate even more loyalty and make them more willing to share positive experiences with those around them. This correlation has been verified through numerous studies (Oppermann, 2000; Chen \& Hsieh, 2005). In other words, tourists with high level of satisfaction will tend to revisit a tourism destination in the future. 


\section{Research Methods and Materials}

\subsection{Research Models and Hypotheses}

In this study, we aim to evaluate the impact of the factors of destination image on the satisfaction and loyalty of tourists at the tourism destinations in mountain areas of Thanh Hoa province. With reference to a destination image scale adopted by previous studies and the actual conditions of destinations in the mountain areas of Thanh Hoa province, the authors selected 29 scales that constitute destination image, 03 scales that constitute tourist satisfaction and 03 components hat constitute tourist loyalty to a tourism destination. The destination image scale has been synthesized and consulted with leading experts. Therefore, a destination image includes 6 factors: (1) Natural features, (2) Travel resources, (3) Infrastructure, (4) Government support, (5) Price perceiveds and (6) Human factors.

The research model is established on the assumptions that factors constituting a destination image have direct impact on tourist satisfaction and tourist satisfaction have direct impact on their loyalty to the mountain destinations in Thanh Hoa province as shown in Figure 1. Factors that constitute a destination image include:

Lin, Morais, Kerstetter, and Hou (2007) shown that natural features is including aspects of natural landscape, environment, atmosphere, weather at tourism destinations. Travel resources are aspects of the convenience or diversity of the products/services offered at the destination. Travel resources can also be viewed as convenience attributes offered for tourists at a destination.

Infrastructure system: Basic utilities such as roads, transport vehicles, convenient access to transport system (Lin, Morais, Kerstetter, \& Hou, 2007; Nguyen \& Nguyen, 2009).

Government support: These are government support policies for public administrative services, legal systems, information systems to serve local target tourists (Nguyen \& Nguyen, 2009; Dao, Tran, Bui, \& Nguyen, 2014).

According to Monroe and Krishman (1985), Price perceiveds are what customers technically pay for a transaction, what they give away or sacrifice, measured in a monetary term, to get the desired goods and services; Jacoby and Olson (1977) shown that the price perceived is a measure of a tourist's level of sacrifice and its value relative to what they will receive.

Human factors: Include various aspects such as: Behavior, attitude of local people as well as skills, knowledge, capacity of service employees in restaurants, hotels, resorts, etc.
Through previous studies, it has been shown that positive destination image will have a strong impact on tourist satisfaction; and tourist satisfaction also has a positive effect on tourist loyalty.

On that basis, the author proposes the following research hypotheses. Figure 1 displays our proposed research model.

H1: Natural features has a positive impact on tourist satisfaction at the mountain destinations in Thanh Hoa province.

H2: Travel resources has a positive impact on tourist satisfaction at the mountain destinations in Thanh Hoa province.

H3: Infrastructure has a positive effect impact on tourist satisfaction at the mountain destinations in Thanh Hoa province.

H4: Government support has a positive impact on tourist satisfaction at the mountain destinations in Thanh Hoa province.

H5: Price perceived has a positive impact on tourist satisfaction at the mountain destinations in Thanh Hoa province.

H6: Human factors have a positive impact on tourist satisfaction at the mountain destinations in Thanh Hoa province.

H7: Satisfaction has a positive impact on tourist loyalty at the mountain destinations in Thanh Hoa province.

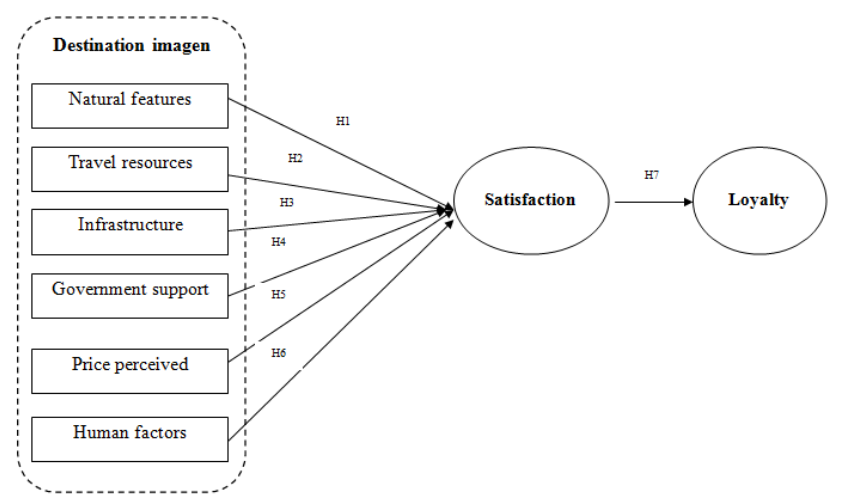

Figure 1: Model proposed by the authors

\subsection{Description of Study Data}

\subsubsection{Subjects of Study}

Subjects of the study were selected from the tourists at the mountain destinations in Thanh Hoa province using the non-probability sampling method and evaluation of scholars. We used a 5-point likert scale with 1 being totally disagree and 5 being totally agree. All scale factors are unidirectional. 


\subsubsection{Scope of Study Sample}

Hair, Black, Babin, Anerson, and Tatham (1998) recommends that if the sample size is around 100, the loading factor standard must be greater than 0.5 . Bollen (1986) proposed the ratio of 5 observations per estimated parameter in the multivariate analysis. In the research, there are 35 variable observations, so the minimum sample size should be equal to $35 * 5=175$ samples. The study has a sample size of 500 tourists at the mountains tourism destination in Thanh Hoa, which can meet the requirements and be generalizable, representative of the total study; the total number of valid questionnaires collected and processed was 385 questionnaires.

\subsubsection{Survey Method}

The study was conducted through direct interviews and questionnaires with tourists at mountain destinations in Thanh Hoa province using non-probability sampling methods.

\subsubsection{Analytical Methods}

The research uses following methods: the exploratory factor analysis (EFA), confirmatory factor analysis (CFA), and structural equation model (SEM) with SPSS.20 software in combination with AMOS.20. Cronbach's Alpha testing is used to evaluate the reliability of the scale of variables, and to eliminate the inadequate variables. Exploratory factor analys is for developing a scale and identifying an underlying relationship between measured variables. The confirmatory factor analysis is used to redefine univariate, multivariate, convergent and discriminant values of concepts. From the CFA results, structural equation analysis is used to construct and validate relevance of the research model and also assess the impact level of independent variables on the dependent variable.

\subsubsection{Questionnaire}

For this study, the authors design a questionnaire consisting of two parts:

Part 1: General information.

Part 2: Tourists' assessment concerning the impact of tourism destination on tourist satisfaction and tourist satisfaction on tourist loyalty.

\section{Results}

\subsection{Descriptive Statistics}

The study has a sample size of 500 tourists, resulting in a total of 385 valid survey questionnaires collected and processed. Demographic information of the observed sample is presented in Table 1.

Table 1: Description of demographic characteristics of the surveyed sample

\begin{tabular}{|c|c|c|}
\hline Content & Frequency & Percent \\
\hline \multicolumn{3}{|l|}{ Gender } \\
\hline Male & 198 & 51.4 \\
\hline Female & 187 & 48.6 \\
\hline Total & 385 & 100.0 \\
\hline \multicolumn{3}{|l|}{ Age } \\
\hline Under 18 & 84 & 21.8 \\
\hline $19-30$ years & 148 & 38.4 \\
\hline $31-50$ years & 107 & 27.8 \\
\hline Above 50 years & 46 & 11.9 \\
\hline Total & 385 & 100.0 \\
\hline \multicolumn{3}{|l|}{ Income } \\
\hline Under 5 million & 113 & 29.4 \\
\hline 5-10 million & 180 & 46.8 \\
\hline 11-15 million & 57 & 14.8 \\
\hline over 15 million & 35 & 9.1 \\
\hline Total & 385 & 100.0 \\
\hline \multicolumn{3}{|l|}{ Education } \\
\hline $\begin{array}{l}\text { College, high school } \\
\text { or lower }\end{array}$ & 95 & 24.7 \\
\hline Bachelor degree & 242 & 62.9 \\
\hline Post graduate degree & 48 & 12.5 \\
\hline Total & 385 & 100.0 \\
\hline
\end{tabular}

\subsection{Assessment of the Impact on Tourist Satisfaction}

\subsubsection{Test of the Reliability of Scale}

One of the nonular methods for testing the reliahility of a scale is to test the Cronhach's Alnha coefficient Cronbach's Alpha coefficient will be run separately for each independent factor, thereby measuring the consistency among the variables of the same factor because the higher and higher the consistency of observed variables is, the higher and higer the reliability of the scale is. Hair et al. (1998) shown that each factor when heino tested must have Cronhach's Alnha score of 06 and over to he considered acceptable. If the factor's Cronbach's Alpha score reaches from 0.7 to 0.8 , it can be used and if it ranges from 0.8 to 1 , the reliability is high 
Meanwhile, the item-total correlation coefficient of each variable must reach 0.3 and over to be included in the next analysis. The variables, the coefficient of which is less than 0.3 , will be considered as non-informative variable and excluded before the factor analysis.

Software SPSS.20 was used to support the analysis of the data collected after exclusion. The authors excluded 4 variables NAT4, NAT 5, TRA6, TRA7 due to their Cronbach's Alpha coefficients < 0.3 (Hair et al., 1998). Among 31 variables of the remaining model, 25 independent variables and 6 dependent variables are included in the EFA model.

\subsubsection{Analysis of Exploratory Factor}

According to Anderson and Gerbing (1988), Principal Axis Factoring was used with Promax rotation and factor loading coefficients $\geq 0.5$ to incorporate remaining variables into Exploratory Factor Analysis (EFA) model for the purposes of scale validation. We have the resultant KMO coefficient $=0.864>0.5$; Bartlett's Test statistics are 5126,739 with significance level of $0,000<0.05$; Cumulative of Variance is $73.073 \%$ ( $>50 \%$ ). This proves that the analytical data is perfectly relevant. Thus, all factor loading coefficients are greater than 0.5 ; explained variance is greater than $50 \%$, the remaining 31 observed variables are grouped exactly as the original scale.

It is shown in the EFA results the following factors:

Factor 1: includes the observed variables TRA1-TRA5 (except TRA6, TRA7) and is named "Travel resources" (TRA).

Factor 2: includes observed variables INF1-INF5 and is named "Infrastructure" (INF).

Factor 3: includes observed variables GOV1-GOV4 and is named "Government support" (GOV).

Factor 4: includes observed variables PRI1-PRI4 and is named "Price perceived" (PRI).

Factor 5: includes observed variables HUM1-HUM4 and is named "Human factors" (HUM).

Factor 6: includes observed variables NAT1-NAT3 (except NAT4, NAT5) and is named "Natural features" (NAT).

Factor 7: includes observed variables SAT1-SAT3 and is named "Satisfaction" (SAT).

Factor 8: includes observed variables LOY1- LOY3 and is named "Loyalty" (LOY).

After EFA exploratory analysis, it can be seen that the model has no difference from the research model, only some observed variables are unreliable, so they are excluded from the studied variables. There is no new factor group as Table 2:
Table 2: Analysis result of the second exploratory factor

\begin{tabular}{|c|c|c|c|c|c|c|c|c|}
\hline \multicolumn{9}{|c|}{ Pattern Matrix $^{a}$} \\
\hline & \multicolumn{8}{|c|}{ Factor } \\
\hline & 1 & 2 & 3 & 4 & 5 & 6 & 7 & 8 \\
\hline TRA2 & .936 & & & & & & & \\
\hline TRA3 & .873 & & & & & & & \\
\hline TRA5 & .799 & & & & & & & \\
\hline TRA1 & .726 & & & & & & & \\
\hline TRA4 & .700 & & & & & & & \\
\hline INF2 & & .834 & & & & & & \\
\hline INF4 & & .779 & & & & & & \\
\hline INF5 & & .750 & & & & & & \\
\hline INF3 & & .740 & & & & & & \\
\hline INF1 & & .688 & & & & & & \\
\hline GOV2 & & & .865 & & & & & \\
\hline GOV4 & & & .824 & & & & & \\
\hline GOV3 & & & .817 & & & & & \\
\hline GOV1 & & & .748 & & & & & \\
\hline PRI1 & & & & .860 & & & & \\
\hline PRI2 & & & & .838 & & & & \\
\hline PRI4 & & & & .668 & & & & \\
\hline PRI3 & & & & .665 & & & & \\
\hline HUM2 & & & & & .864 & & & \\
\hline HUM3 & & & & & .854 & & & \\
\hline HUM1 & & & & & .758 & & & \\
\hline HUM4 & & & & & .753 & & & \\
\hline NAT3 & & & & & & .810 & & \\
\hline NAT2 & & & & & & .773 & & \\
\hline NAT1 & & & & & & .576 & & \\
\hline LOY1 & & & & & & & .763 & \\
\hline LOY3 & & & & & & & .691 & \\
\hline LOY2 & & & & & & & .632 & \\
\hline SAT2 & & & & & & & & .867 \\
\hline SAT3 & & & & & & & & .719 \\
\hline SAT1 & & & & & & & & .599 \\
\hline & & & KM & 0,864 & & & & \\
\hline & & nula & of $\mathrm{V}$ & riance & $\%): 7$ & 073 & & \\
\hline
\end{tabular}

\subsubsection{Analysis of Confirmatory Factor}

It can be seen in the EFA results that there are eight key concepts in the research model. To measure the model's suitability with market information, we use Chi-square (CMIN), which is adjusted by degrees of freedom (CMIN/df), CFI, GFI, TLI and RMSEA indices. The model is considered to be suitable with the market data when it receives TLI, CFI $\geq 0.9$; GFI $\geq 0.8$, CMIN/df $\leq 3$ RMSEA $\leq 0.08$ (Bentler \& Bonelt, 1980; Carmines \& McIver, 1981; 
Steiger, 1990). It is shown in the CFA results of the research model that it is suitable with the market information (see Figure 2).

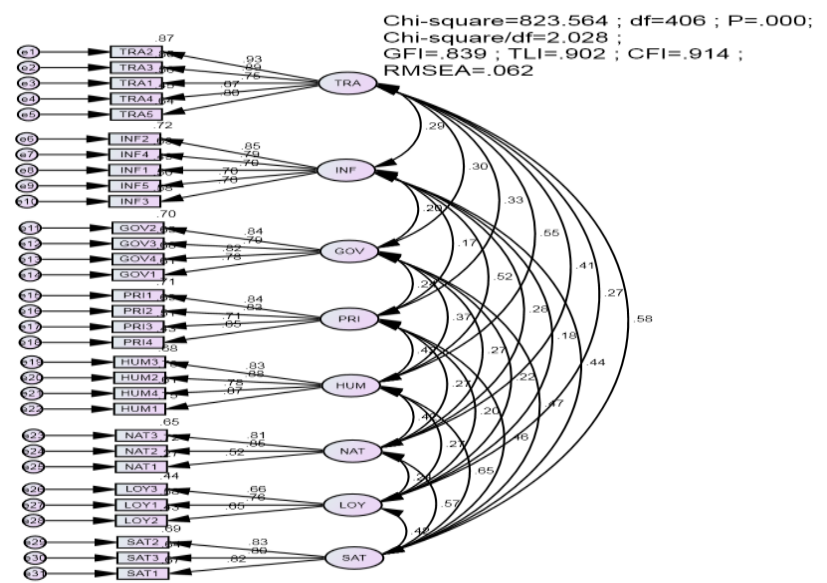

Figure 2: Results of CFA of the organizational culture scale (standardized)

P-value results of the observed variables representing the factors all have the value sig. $=0.000$ so the observed variables are affirmatively considered to have good representation for the CFA model factor. The correlation coefficient of each pair of concepts is different from 1 in the reliability of $95 \%(\mathrm{P}-$ Value value $=0.000)$ so the concepts achieve discriminant value. The weights (normalized) all are more than 0.5 and weights (nonnormalized) are statistically significant (sig. $<0.000)$ so the concepts achieve convergence value. This measurement model is compatible with market data and there is no correlation among measurement errors so it achieves uniqueness.

The critical measurement model for research concepts is shown in Figure 2. The critical model is a model of established factors that are freely interrelated. CFA analysis results demonstrate that: Chisquare/df $=2.028<3$, CFI $=$ $0.914>0.9 ; \mathrm{TLI}=0.902>0.9 ; \mathrm{GFI}=0.839>0.8$ và RMSEA $=0.062<0,8$ (Bentler \& Bonelt, 1980; Carmines $\&$ McIver, 1981; Steiger, 1990). All factor weights of each observed variable are greater than 0.5 , so it can be viewed that the model achieves convergence value (Figure 2).

\subsubsection{Test of Reliability after Exploratory Factor Analysis}

It can be seen after Cronbach's Alpha test that Cronbach's Alpha coefficient of each factor has a value of more than 0.7 and the item-total correlation coefficient is more than 0.3 , therefore, the scales all are reliable. The combined reliability and Average Variance Extracted of each factor have values greater than 0.5 so the factors in the model are reliable (see Table 3 ).

Table 3: Test results of reliability of the scale

\begin{tabular}{|c|c|c|c|c|c|}
\hline Factor & $\begin{array}{c}\text { Number of observed } \\
\text { variables }\end{array}$ & $\begin{array}{c}\text { Cronbach's } \\
\text { Alpha reliability }\end{array}$ & $\begin{array}{c}\text { Combined } \\
\text { reliability (CR) }\end{array}$ & $\begin{array}{c}\text { Average Variance } \\
\text { Extracted } \\
\text { (AVE) }\end{array}$ & $\begin{array}{c}\text { Convergence and } \\
\text { discriminant } \\
\text { values }\end{array}$ \\
\hline Natural features (NAT) & 3 & 0,764 & 0,776 & 0,546 & Satisfactory \\
\hline Travel resources (TRA) & 5 & 0,906 & 0.8907 & 0,664 & Satisfactory \\
\hline Infrastructure (INF) & 5 & 0,874 & 0,875 & 0,654 & Satisfactory \\
\hline $\begin{array}{c}\text { Government support } \\
\text { (GOV) }\end{array}$ & 4 & 0,873 & 0,883 & 0,585 & Satisfactory \\
\hline Price perceived (PRI) & 4 & 0,844 & 0,848 & 0,705 & Satisfactory \\
\hline Human factors (HUM) & 4 & 0,903 & 0,905 & 0,668 & Satisfactory \\
\hline Satisfaction (SAT) & 3 & 0,854 & 0,858 & 0,527 & Satisfactory \\
\hline Loyalty (LOY) & 3 & 0,731 & 0,769 & & 0 \\
\hline
\end{tabular}

\subsubsection{Structural Equation Modeling (SEM)}

The study used SEM linear structure model to evaluate the suitability of the research model and to validate the correlations in the model. SEM analysis results with the degree of freedom $\mathrm{df}=412$, Chi-square $=823,792$ with $\mathrm{p}=$ $0.000<0.05$, Chi-square $/ \mathrm{df}=1.999<3$, CFI $=0.916>0.9$, $\mathrm{TLI}=0.905>0.9 ;$ GFI $=0.839>0.8 ;$ RMSEA $=0.061<$ 0.8. Therefore, it can be confirmed that the model is well suited to the market data (see Figure 3).
Table 4 displays the results of SEM regression with $\mathrm{P}$ $<5 \%$ which confirms that all hypotheses are accepted. This is to say all factors constituting a destination image, including: Natural features (NAT); Travel resources (TRA); Infrastructure (INF); Government support (GOV); Price perceived (PRI) and Human factors (HUM), have a positive impact on tourist satisfaction. In particular, the most influential factor is Natural features (with impact coefficient $\beta=0.260$ ), followed by Human factors (with $\beta$ 
$=0.214$ ); Travel resources (with $\beta=0.212$ ); Government support (with $\beta=0.195$ ); Price perceived (with $\beta=0.161$ ) while the least influential factor is Infrastructure (with $\beta=$ 0.126); On the other hand, the research results also demonstrate that tourist satisfaction has a strong impact on tourist loyalty, with the coefficient $\beta=0.422$; This research result is also consistent with previous studies.

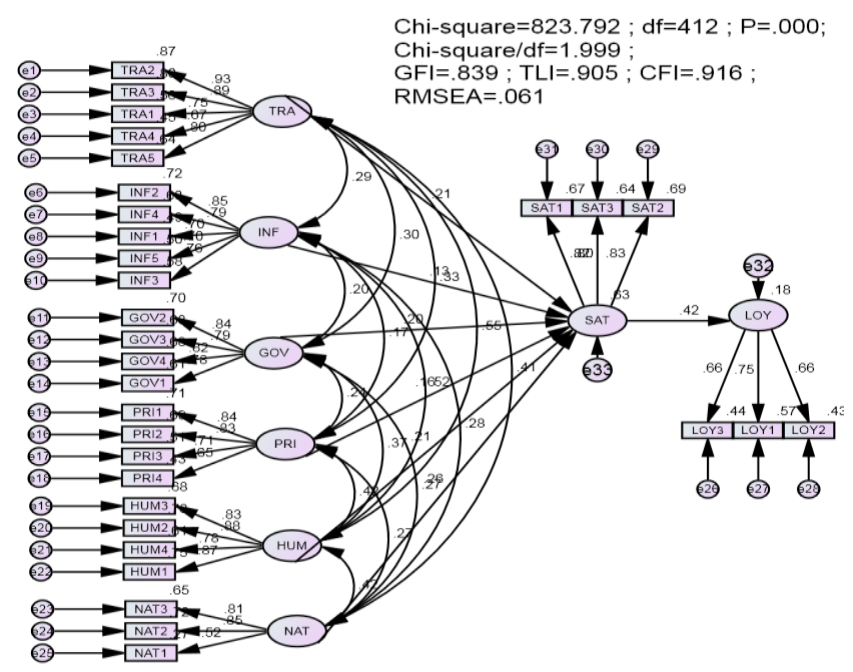

Figure 3: Standardized Structural Equation Modeling (SEM)

Table 4: Coefficients of regression model SEM and test results of the model's hypotheses

Hypothesis FactorEstimateS.E.C.R.P-valueResult
\begin{tabular}{|c|c|c|c|c|c|c|c|c|}
\hline & \multicolumn{2}{|c|}{} & & & & & \\
\hline H1 & SAT & $<---$ & NAT & .260 & .072 & 4,217 & $* * *$ & $\begin{array}{c}\text { Accep } \\
\text { table }\end{array}$ \\
\cline { 2 - 9 } H2 & SAT & $<---$ & INF & .126 & .060 & 2,106 & .035 & Accep \\
\hline H3 & SAT & $<---$ & GOV & .195 & .055 & 3,535 & $* * *$ & table \\
\hline H4 & SAT & $<---$ & PRI & .161 & .059 & 2,814 & .005 & Accep \\
\hline H5 & SAT & $<---$ & HUM & .214 & .093 & 2,830 & .005 & table \\
\hline H6 & SAT & $<---$ & TRA & .212 & .060 & 3,462 & $* * *$ & Accep \\
\cline { 2 - 9 } H7 & LOY & $<---$ & SAT & .422 & .048 & 5,257 & $* * *$ & table \\
\hline
\end{tabular}

\subsubsection{Assessment of the Impact by Constituent Factors on Tourist Loyalty}

In the loyalty model for tourism destinations at the mountain region in Thanh Hoa province, apart from direct impact from tourist satisfaction, tourist loyalty is also indirectly impacted by the destination image's constituent factors. For assessment of the impact by tourist satisfaction and the destination image's constituent factors on tourist loyalty, the authors used direct, indirect and aggregate impact factors for overall assessment. The results indicate that the most influential impact is satisfaction $(\beta=0.422)$, followed by Natural features $(\beta=0.110)$; Human factors $(\beta$ $=0.91)$; Travel resources $(\beta=0.90)$; Government support $(\beta=0.082)$; Price perceived $(\beta=0.068)$; and finally Infrastructure $(\beta=0.053)$ (see Table 5).

Table 5: Impact of factors on tourist loyalty

\begin{tabular}{|c|c|c|c|c|c|c|c|c|}
\hline \multirow{3}{*}{ Factor } & Impact & NAT & HUM & PRI & GOV & INF & TRA & SAT \\
\hline \multirow{3}{*}{ SAT } & Direct Impact & .260 & .214 & .161 & .195 & .126 & .212 & .000 \\
\cline { 2 - 10 } & Indirect Impact & .000 & .000 & .000 & .000 & .000 & .000 & .000 \\
\cline { 2 - 10 } & Total Impact & .260 & .214 & .161 & .195 & .126 & .212 & .000 \\
\hline \multirow{3}{*}{ LOY } & Direct Impact & .000 & .000 & .000 & .000 & .000 & .000 & .422 \\
\cline { 2 - 10 } & Indirect Impact & .110 & .091 & .068 & .082 & .053 & .090 & .000 \\
\cline { 2 - 10 } & Total Impact & .110 & .091 & .068 & .082 & .053 & .090 & .422 \\
\hline
\end{tabular}

\section{Recommendations}

For rapid and sustainable tourism development in the mountain areas of Thanh Hoa province in the upcoming time, the authors would like to propose some administrative implications to maintain and improve the quality of services and attributes that are likely to reward tourist satisfaction, as well as remedy negative attributes causing visistor dissatisfaction, thus contributing to improved quality of tourism destinations in the mountain areas of Thanh Hoa province.

\subsection{Promoting Natural Tourism Resources}

Research results reveal that tourists are extremely satisfied with favorable attributes such as "Great and majestic forests and mountains", "Many waterfalls and whirlpools with harmonious and exclusive scenery". This convincingly proves that the mountain region in Thanh Hoa province boasts many picturesque natural landscapes, such as: Pu Luong, $\mathrm{Pu} \mathrm{Hu}$ and Xuan Lien Nature Reserves; Cam 
Thuy sacred fish stream; Cua Dat Lake; Thach Thanh Elephant Waterfall, etc. Therefore, it is essential to develop this type of tourism in an intensive approach in order to promote the potential of natural tourism resources in Thanh Hoa mountain destinations. It is also suggested to promote the promotion and training of a tourism dedicated workforce.

In addition, local authorities of Thanh Hoa province and mountain districts should attach special attention to sustainable eco-tourism development in order to maintain and develop ecological strength in the locality.

\subsection{Raising Awareness of Environmental Protection}

In order to raise and maintain the community awareness of environmental protection, effective exploitation and protection of natural landscapes for the mountain areas in Thanh Hoa province, the authorities, planners and stakeholders should immediately come up with stringent policies and measures to prevent and minimize the pollution, degradation and environmental incidents caused by human activities during the master planning.

Prevention of at-source pollution and contamination for projects related to the construction of tourism technical and physical facilities such as accommodation establishments, entertainment and recreation facilities, etc. is also encouraged for sustainable development of eco-tourism zones.

It is also very crucial that in parallel with the above measures, adequate attention should be attached to the protection of forests and fresh water sources because forests create fresh air and preserve fresh water sources, which is a life-sustaining element for local people, especially ethnic minorities such as Thai, Muong, Dao, etc. living in this locality.

Community tourism destinations need to establish a tourist and environment help center to provide tourists with necessary information and protect the environment.. Local communities should be empowered by widespread sharing of information and knowledge about tourism destinations, as well as raising awareness about the importance of environmental protection to such destinations.

\subsection{Building Local Cultural Identity}

Image of local people and cultural identity is an extremely crucial factor that make up the tourism brand of a destination. The mountain region of Thanh Hoa province is a destination with strong advantage in this regard, so local authorities are advised to implement feasible solutions to promote propaganda and awareness raising for local people, thereby building up image of local people and cultural identity of mountain destinations in Thanh Hoa province. It is recommended to elicit local people's pride in traditional cultural values, sense of responsibility to preserve and introduce those cultural beauties to tourists through combined eco-tourism and community tourism in the form of sightseeing, relaxation, cultural tourism - historical sites, etc.

In addition, local authorities should constantly focus on collection, restoration and promotion of tangible and intangible cultural values, special customs and practices of Thai, Muong people, as well as eradicating evil customs in marriage, funerals, festivals, etc.; preservation of folk songs, dances, festivals in competitions and shows as well as the humanistic literatures (e.g. the epic "The Birth of the Earth and Water" of Muong people), folk poets and proverbs, bamboo dance, "xoe" dance, "gong" dance, "khap giao duyen" dance, "kin chiêng booc may" dance of ethnic minorities such as Muong, Thai, etc. during tourism development.

\subsection{Building Exclusive Tourist Products}

In the upcoming time, Thanh Hoa province should focus on community-based high quality resort tourism and and eco-tourism. The exploitation of nature discovery and resort tours, together with the use of local people as tour guides, should be effectively promoted. This is supposed to create an unique image for those who visit the mountain region of Thanh Hoa province. In addition, it is essential to exploit the local traditional cultural values for tourism development. A special focus should be made on developing cultural tourism, spiritual tourism, historical sites and archaeological relics; Every year, themed festivals should be held at historical sites.

Adequate propaganda and advertisement campaigns should be targeted at tourists who visit Thanh Hoa mountains in order to elicit their desire to have an immerse experience in the daily life of the local community, enjoy regional specialties such as Co Lung Duck, Song Ma Hemibagrus Fish, Buffalo Meat with Lom leaves, Bitter Soup, Straw Liquor, etc. At the same time, the restoration of traditional craft villages should be focused to provide souvenir products for tourists, thus meeting their tourism needs and raising incomes for local people.

\subsection{Strengthening the Support of Local Authorities for Tourism Activities}

Government support is the support of public 
administrative services, system of laws and information systems for local target tourists. In the upcoming time, in order to develop tourism at the mountain destinations in Thanh Hoa province, local governments need to have specific mechanisms and policies to attract capital investment to take advantage of tourism potential in this locality. In addition, local tourism management agencies are also suggested to strengthen the state management of tourism in the locality, build a database of tourism potentials, accommodation facilities and information systems to serve every need of tourists.

\subsection{Developing a Price Policy}

Validation results indicate that tourists are satisfied with the services and prices of the accommodation facilities. The development and competition helps accommodation facilities improve their quality at affordable prices. The introduction of homestay accommodation provides tourists with a brand new way to have a closer experience and opportunity to participate in cultural festivals and activities of local people.

However, tourists are not satisfied with the price of food service and vehicle rental facilities in the tourism destinations. This requires all levels of government authority to come up with adequate attention, appropriate incentives and management policies to achieve their satisfaction.

\section{References}

Anderson, J. C., \& Gerbing, D. W. (1988). Structural equation modeling in practice: A review and recommended two-step approach. Psychological Bulletin, 103(3), 411. https://doi.org/10.1037/0033-2909.103.3.411.

Ba, H., Thu, P., Chi, T., Thanh, H., \& Huy, C. (2020). Solutions to attract investment capital for tourism development: Evidence from Vietnam economy. Accounting, 6(2), 209-214. DOI: 10.5267/j.ac.2019.10.002

Bentler, P. M., \& Bonett, D. G. (1980). Significance tests and goodness of fit in the analysis of covariance structures. Psychological Bulletin, 88(3), 588. DOI: 10.1037/00332909.88.3.588

Bollen, K. A. (1986). Sample size and Bentler and Bonett's nonnormed fit index. Psychometrika,51(3), 375-377. https://doi.org/10.1007/BF02294061

Bigne, J. E., Sanchez, M. I., \& Sanchez, J. (2001). Tourism image, evaluation variables and after purchase behaviour:interrelationship. Tourism Management, 22(6), 607-616. https://doi.org/10.1016/S0261-5177(01)00035-8

Carmines, E. G. \& McIver, J. P. (1981). Analyzing models with unobserved variables: Analysis of covariance structures. In G.W. Bohmstedt, \& E. F. Borgatta (ed.), Social measurement: Current issues (pp.66-115). Beverly Hills, CA: Sage
Publications. DOI: 10.4236/psych.2013.411120

Chen, Y., \& Hsieh, T. (2005). Correlation of service quality of Hot Spring Hotels, customer satisfaction, customer loyalty and life style. Paper presented at Fourth Annual Asia Pacific forum for graduate students research in Tourism. Retrieved from https://www.academia.edu/8117959

Cronin, J. J. Jr., \& Taylor, S. A. (1992). Measuring service quality: a reexamination and extension. Journal of Marketing, 56(3), 55-68. DOI: $10.2307 / 1252296$

Crosby, L. A., Evans, K. R., \& Cowles, D. (1990). Relationship quality in services selling: an interpersonal influence perspective. Journal of Marketing, 54(3), 68-81. https://doi.org/10.1177/002224299005400306

Chi, C. G. Q., \& Qu, H. (2008). Examining the structural relationships of destination image, tourist satisfaction and destination loyalty: An integrated approach. Tourism Management, 29(4), 624-636. DOI: 10.1016/j.sbspro.2015.01.1198

Chon, K. S. (1989). Understanding recreational traveler's motivation, attitude and satisfaction. The Tourist Review, 44(1), 3-7.

Chon, K. S., \& Olsen, M. D. (1991). Functional and symbolic congruity approaches to consumer satisfaction/dissatisfaction in tourism. Journal of the International Academy of Hospitality Research, 1991(3), 2-22.

Dao, T. K., Tran, M. T., Bui, Q. T., \& Nguyen, V. D (2014). Impact of local attributes on the satisfaction of investment busineses: Evidence from Hai Duong province. Journal of Economics and Development, 210(12), 43-52.

Hair, J. F., Black, W. C., Babin, B. J., Anderson, R. E., \& Tatham, R. L. (1998). Multivariate data analysis. Upper Saddle River, NJ: Prentice Hall.

Homburg, C., \& Giering, A. (2001). Personal characteristics as moderators of the relationship between customer satisfaction and loyalty - an empirical analysis. Psychology \& Marketing, 18(1), 43-66. https://doi.org/10.1002/15206793(200101)18:1<43::AID-MAR3>3.0.CO;2-I.

Ibrahim, E. E. B., \& Gill, J. (2005). A positioning strategy for a tourist destination, based on analysis of customer's perceptions and satisfactions. Marketing Intelligence and Planning, 23(2). 172-188. http://dx.doi.org/10.1108/02634500510589921.

Jacoby, J., \& Olson, J. C. (1977). Consumer response to price: An attitudinal, information processing perspective. In Y. Wind \& P. Greenberg (ed.), In Moving Ahead with Attitude Research (pp.73-86), Chicago, IL: American Marketing Association.

Kim, M. J., \& Park, C. J. (2019). Does Customer Delight Matter in the Customer Satisfaction-Loyalty Linkage? Journal of Asian Finance, Economics and Business, 6(3), 235-245. https://doi.org/10.13106/jafeb.2019.vol6.no3.235

Kotler, P., Ang, S. H., Leong, S. M., \& Tan, C.T. (1999). Marketing Management: An Asian Perspective. Upper Saddle River, NJ: Prentice Hall Inc.

Kozak, M., \& Rimmington, M. (2000). Tourist satisfaction with Mallorca, Spain, as an off-season holiday destination. Journal of Travel Research, 38(3), 260-269. https://doi.org/10.1177/004728750003800308.

Lee, J. W., \& Syah, A. M. (2018). Economic and environmental impacts of mass tourism on regional tourism destinations in Indonesia. Journal of Asian Finance, Economics and Business, 
5(3), 31-41. http://doi.org/10.13106/jafeb.2018.vol5.no3.31

Lee, T. H. (2009). A structural model to examine how destination image, attitude, and motivation affect the future behavior of tourists. Leisure $\quad$ Sciences, 31(3), 215-236. https://doi.org/10.1080/01490400902837787.

Lin, C. H., Morais, D. B., Kerstetter, D. L., \& Hou, J. S. (2007). Examining the role of cognitive and affective image in predicting choice across natural, developed, and theme-park destinations. Journal of Travel Research,46(2), 183-194. https://doi.org/10.1177/0047287506304049

Mannell, R. C., \& Iso-Ahola, S. E. (1987). Psychological nature of leisure and tourism experience. Annals of Tourism Research, 14(3), 314-331. https://doi.org/10.1016/0160-7383(87)901058.

San Martín, H., \& Rodríguez Del Bosque, I. A. (2008). Exploring the cognitive-affective nature of destination image and the role of psychological factors in its formation. Tourism Management, 29(2), 263-277. DOI: 10.1016/j.tourman.2007.03.012.

Monroe, K. B., \& Krishnan, R. (1985). The effect of price on subjective product evaluations. Perceived Quality, 1(1), 209232

Nyaupane, G. P., Timothy, D. J., \& Poudel, S. (2015). Understanding tourists in religious destinations: A social distance perspective. Tourism Management, 48, 343-353. DOI: 10.1016/j.tourman.2014.12.009

Nguyen, D. T., \& Nguyen, T. M. T. (2009). Scientific research in business administration. Honoi, Vietnam: Statistical Publishing House.

Nguyen, Q. N., Nguyen, T. B. C., \& Tran, N. L. (2012). Factors affecting an Giang local people's decision on participation in community tourism. Journal of Science, 23b, 194-202.

Oppermann, M. (2000). Tourism destination loyalty. Journal of Travel Research, 39(1), 78-84. https://doi.org/10.1177/004728750003900110.

Piewdang, S., Mekkamol, P., \& Untachai, S. (2013). Measuring spiritual tourism management in community: A case study of Sri Chom Phu Ongtu Temple, Thabo district, Nongkhai province, Thailand. Procedia-Social and Behavioral Sciences, 88, 96-107. DOI: 10.1016/j.sbspro.2013.08.485
Pham, T. L. (2002). Ecotourism: Theoretical and practical issues in Vietnam. Honoi, Vietnam: Education Publishing House.

Phan, M. D., \& Dao, T. K. (2017). Impact of destination image, emotion value on tourist satisfaction and loyalty: Case studies of Dalat City. Journal of Economics and Development, 236(1), 82-91.

Phan, M. D. (2016). Destination image and psychosocial values affecting the satisfaction and loyalty of tourists to Dalat City (Doctoral thesis). University of Economics Ho Chi Minh City.

Steiger, J. H. (1990). Structural model evaluation and modification: An interval estimation approach. Multivariate Behavioral Research, 25(2), 173-180. https://doi.org/10.1207/s15327906mbr2502_4.

Sun, X., Chi, C. G. Q., \& Xu, H. (2013). Developing destination loyalty: The case of Hainan Island. Annals of Tourism Research, 43, 547-577. DOI: 10.1016/j.annals.2013.04.006.

Tribe, J., \& Snaith, T. (1998). From SERVQUAL to HOLSAT: holiday satisfaction in Varadero, Cuba. Tourism Management, 19(1), 25-34. https://doi.org/10.1016/S0261-5177(97)00094-0

Um, S., Chon, K., \& Ro, Y. (2006). Antecedents of revisit intention. Annals of Tourism Research, 33(4), 1141-1158. DOI: 10.1016/j.annals.2006.06.003.

Wu, C. W. (2016). Destination loyalty modeling of the global tourism. Journal of Business Research,69(6), 2213-2219. DOI: 10.1016/j.jbusres.2015.12.032.

Vengesayi, S. (2003). A conceptual model of tourism destination competitiveness and attractiveness. In ANZMAC 2003 Conference Proceedings (pp.637-647), Adelaide, University of South Australia, 1-3 December.

Yoon, Y., \& Uysal, M. (2005). An examination of the effects of motivation and satisfaction on destination loyalty: a structural model. Tourism Management, 26(1), 45-56. DOI: 10.1016/j.tourman.2003.08.016.

Zeithaml, V. A., Berry, L. L., \& Parasuraman, A. (1996). The behavioral consequences of service quality. Journal of Marketing, 60(2), 31-46. DOI: 10.2307/1251929.

Zhang, H., Fu, X., Cai, L. A., \& Lu, L. (2014). Destination image and tourist loyalty: A meta-analysis. Tourism Management, 40, 213-223. http://dx.doi.org/10.1016/j.tourman.2013.06.006. 